\title{
Review
}

\section{Ingenious citizenship: Recrafting democracy for Social change}

\author{
Charles T. Lee \\ Durham and London: Duke University Press, 2016, 312pp., \\ ISBN 978-0822360377
}

Contemporary Political Theory (2018) 17, S59-S61. https://doi.org/10.1057/s41296017-0115-1; published online 16 May 2017

This is a captivating and provocative book that seeks to recenter the agency of the subordinated at the heart of citizenship theory. To challenge current theories of democratic citizenship, it asks the reader to re-imagine the figures of political theory and the style of criticizing liberal thinking. Critical theorists have deployed the agency of the oppressed in order to move away from various kinds of liberalisms. In Karl Marx's debate with liberal economists, the proletarians emerged as leading figures fighting capitalism; Michel Foucault made use of inferior knowledge to decapitate the positivism of a liberal model of power; and in Gender Trouble Judith Butler mobilized non-normative queer practices against liberal feminist arguments about women's oppression. What is different in Charles Lee's book? In his argument, when it comes to the figures of an ingenious citizenship, we have to look to "the abject subjects" who make do in their ordinary lives (p. 14). The new figures of theory production are domestic workers, sex workers, trans people, and suicide bombers, who are ingenious in that they "come up with original and resourceful ways" to act (p. 16). When it comes to style, his advice is to abandon pregiven tactics and to appropriate the power of the dominant in the manner of martial arts fighters. Like Bruce Lee, we are invited to use "no way as way" and turn "the logic and the force of the attack to exert a counterattak" (p. 251). The agency of the subordinated is powerful not because of its emancipatory intentions, but because of their tactical theft of the liberal vocabulary centered on law and rights.

This book's critical contribution is to re-orient our critical tools toward actions and identities of the subordinated. It seeks to take us beyond an Anglo-American mode of thinking, and it fundamentally asks political theorists to think about their work as part of an anti-racist queer political project. This is where Lee's work seeks to intervene in the field of political theory. Rather than praising an avant garde project of social transformation, the book urges us to embrace the politics without

(C) 2017 Macmillan Publishers Ltd. 1470-8914 Contemporary Political Theory Vol. 17, S2, S59-S61 www.palgrave.com/journals 
politics by agents who obtain "citizenship" in non-linear ways. Like Saba Mahmood, Lee wants critical theorists to let go of a progressive conception of agency that is Anglo-centric and liberal. Unlike her, he offers not an Aristotelian and virtue-oriented politics but more tactics for appropriating the power of the oppressor. In this Zen mindset, letting go of an opposition to capitalism to cunningly achieve a better social position is the way to truly destruct capitalism. Lita, a Filipina worker, forces her employer to accept her demands by dropping menstrual blood on the floor. Afro-caribbean migrant sex workers racially exoticize their bodies as "mulatto babes" to survive and preserve their personal histories. Migrant transgender sex workers move from "ordinary women" to "women with male genitalia" to transform uninhabitable spaces within liberal citizenship. Palestinian suicide bombers act by deploying a language of martyrdom and sacrifice to make visible their status of impossible citizens.

While I can follow the author's call to learn from the oppressed, I have trouble accepting his critique of the political "purity" of various transgender and decolonial scholars, who criticize the logic of inclusion in liberal capitalism. In challenging Dean Spade and Chela Sandoval, the author asks us to follow the "contaminated" tactics of his subjects, rather than those of theorists who could be, in some respect, similarly positioned in racialized Global North capitalism. The assumed project of Ingenious Citizenship is to achieve a "normal" life for its subjects and place them in a better position in this world. Although this book delivers its promise well, it also aims to decolonize Western liberalism. I am not convinced that it fully achieves this second goal. Lee's claim is that his subjects, with the exception of suicide bombers, instantiate a better politics because they produce spaces for achieving a liveable life. Unlike the author, Lee's subjects seem to believe that their survival strategies are just that, survival politics, and not a critical queer anti-racist project. In abandoning any theoretical opposition to racialized capitalism, the problem with Lee's "politics without politics" is that it glorifies life and endurance as uncontested goals.

And here is my second point about the lack of critical bite in this decolonial project. Ingenious Citizenship draws on an ideal of representation that assumes legibility for subjects' actions and speech, without thoroughly interrogating the relations of power involved in producing and harnessing their "voices." According to Lee, the Palestinian Authority's use of the figures of suicide bombers is valuable in itself, because it is better positioned than the US-centered "Boycott, Divestment, and Sanctions" advocates to speak for the Palestinians (pp. 238-239). The book seems to endorse the fantasy that you can better speak for somebody if you are closer to them, which sidesteps the critical move to analyze the contexts of the production of these Palestinian "voices." This fiction of representation builds on another fiction of empathy, which is described as a critical step to "decenter our unitary subjectivity" (p. 27). Lee invites us to embrace the abjection of gay black male working class subjects and to follow Robert Mapplethorpe in his strategy of "perversion" so as to understand them. In short, we decolonize heteronormative 
white liberalism if we put ourselves in the position of black gay subjects, as Mapplethorpse sees it.

Yet, like Saydia Hartman, I find that calls to empathize with the humanity of abjected black bodies intensify "the brutal exercise of power" rather than ameliorate their condition (Hartman, 1997, p. 5). Lee's book is critically asking political theory scholars to change their methods, but my worry is that it has inadvertently asked us to feel better that "the abject" is changing the world. A future project that might deepen the author's engagement with critical race studies perhaps would shift his approach, which assumes too easily the legibility of abject subjects and the possibility of our empathizing with them.

What the book does very well is to consolidate and advance an important transformation in innovative scholarship in political theory, which has moved away from appealing to canonical figures to legitimize itself as theory. To the contrary, this book is very bold in asking theorists to think about their field in new ways. First, this book shows that the canon, with its interpretative focus on great thinkers from Plato to Foucault, may be dead and in need of burial. By exploring the life of abject subjects, Lee's "politics without politics" is a form of left populism that is badly needed for its democratic potential, particularly in the right-wing-dominated US politics. In foregrounding a new method and agents, Lee executes a decisive counter-attack on traditional scholarship, which might be poorly equipped to respond to current anti-democratic politics. Second, by drawing on trans and queer studies, as well as on scholarship traditionally taught in comparative American politics, Lee shows us that political theory has fundamentally changed. This book makes it increasingly hard for critical scholars not to engage deeply with a flourishing literature in trans, queer, critical race, and indigenous studies. It urgently asks us to imagine our students as predominantly non-white and queer and to dare to illuminate new types of political life. It recrafts not only democratic notions of agency, but also what we mean when we say "political theory" and think about its relationship to how we act in the world.

\section{Reference}

Hartman, S. (1997). Scenes of Subjection:Terror, Slavery and Self-Making in Nineteenth Century America. New York: Oxford University Press.

Bogdan Popa

Oberlin College, 8 East College Street, Oberlin, OH 44074, USA

bpopa@oberlin.edu

(c) 2017 Macmillan Publishers Ltd. 1470-8914 Contemporary Political Theory Vol. 17, S2, S59-S61 S61 